IZA DP No. 5812

Improving Reading Skills by Encouraging Children to Read: A Randomized Evaluation of the Sa Aklat Sisikat Reading Program in the Philippines

Ama Baafra Abeberese

Todd J. Kumler

Leigh L. Linden

June 2011 


\title{
Improving Reading Skills by Encouraging Children to Read: A Randomized Evaluation of the Sa Aklat Sisikat Reading Program in the Philippines
}

\author{
Ama Baafra Abeberese \\ Columbia University \\ Todd J. Kumler \\ Columbia University \\ Leigh L. Linden \\ University of Texas at Austin \\ and IZA
}

Discussion Paper No. 5812

June 2011

IZA

P.O. Box 7240

53072 Bonn

Germany

Phone: +49-228-3894-0

Fax: +49-228-3894-180

E-mail: iza@iza.org

\begin{abstract}
Any opinions expressed here are those of the author(s) and not those of IZA. Research published in this series may include views on policy, but the institute itself takes no institutional policy positions.

The Institute for the Study of Labor (IZA) in Bonn is a local and virtual international research center and a place of communication between science, politics and business. IZA is an independent nonprofit organization supported by Deutsche Post Foundation. The center is associated with the University of Bonn and offers a stimulating research environment through its international network, workshops and conferences, data service, project support, research visits and doctoral program. IZA engages in (i) original and internationally competitive research in all fields of labor economics, (ii) development of policy concepts, and (iii) dissemination of research results and concepts to the interested public.
\end{abstract}

IZA Discussion Papers often represent preliminary work and are circulated to encourage discussion. Citation of such a paper should account for its provisional character. A revised version may be available directly from the author. 
IZA Discussion Paper No. 5812

June 2011

\section{ABSTRACT}

\section{Improving Reading Skills by Encouraging Children to Read: A Randomized Evaluation of the Sa Aklat Sisikat Reading Program in the Philippines ${ }^{*}$}

We evaluate a program that aims to improve children's reading skills by providing classes with age-appropriate reading material and incentivizing children to read through a 31 day read-a-thon. During the read-a-thon, the program significantly increases the propensity of children to read, causing 20 percent more children to have read a book in the last week at school and increasing the number of books read by 2.3 in the last week and 7.2 in the last month. These increases extend both after the end of the program and outside of school, although at lower rates. The program also increased students' scores on a reading assessment, causing students' scores to improve by 0.13 standard deviations immediately after the program. The effect persisted even after the program ended with an effect of 0.06 standard deviations three months later.

JEL Classification: $\quad$ I21, I28, O15

Keywords: education, reading, development

Corresponding author:

Leigh L. Linden

Department of Economics

Columbia University

Mail Code 3308

420 West 118th Street

New York, NY 10027

USA

E-mail: leigh.linden@austin.utexas.edu

\footnotetext{
* We are indebted to many individuals who were significantly involved with the execution of this experiment. We wish to thank Catherine S. Alcaraz, Marie Angeles, Coly Los Baños, Clarissa Isabelle Delgado, Margarita L Delgado, Norlyn Gregorio, Elizabeth E. Zobel and all of the other staff members of the Sa Aklat Siskat Foundation for their support and assistance during the evaluation. All surveys were conducted by TNS Philippines. Finally, we are grateful to an anonymous donor for generously agreeing to fund this research effort. Without his or her help, this project would not have been possible.
} 


\section{Introduction}

Universal primary education is receiving increased attention due in part to the Millennium Development Goals and Education for All campaigns. However, the average quality of primary schools in many developing countries is notoriously poor. While many countries have succeeded at increasing enrollment rates, many children attend schools that may not be suited to their educational needs (see, for example, Glewwe and Kremer, 2006). Hanushek and Wossmann (2007), for example, document a clear difference in both educational attainment and the quality of education in developed and developing countries. Understanding the nature of education production and identifying viable strategies for increasing educational quality in resource-constrained settings are therefore crucial. Furthermore, effective improvements in reading instruction may be particularly important because existing research suggests reading at an early age lays a necessary foundation for subsequent skill development (Scarborough, 2001).

We assess the potential of a Philippine program that seeks to improve children's reading skills by encouraging reading amongst fourth grade students. Using a randomized controlled trial set in Tarlac province of the Philippines, we analyze the impact of an educational intervention that provides schools with age-appropriate reading material and then incentivizes reading through a 31-day reading marathon. The reading marathon encourages students to read as many books as possible through daily, in-school reading activities such as storytelling sessions, reading games, and posters that display each class's progress.

The RCT sample consisted of all 5,510 fourth-grade students from 100 schools in Tarlac, a province near the capital. Following a baseline assessment of students' reading skills at the start of the academic year, these schools were randomly assigned equally to a treatment and 
control group. The effects of the program were estimated using two follow-up surveys conducted just after the completion of the reading marathon (and four months after the baseline), and then again seven months after the baseline at the end of the academic year. This provides an assessment of the effect of the program immediately following the intervention as well as an assessment of the intervention's effects several months after the NGO has stopped working with the schools. In addition, we test both students' reading skills as well as their knowledge of other subjects to assess the possibility of spillovers.

Overall, the results suggest that encouraging an increased use of age-appropriate reading materials by students is a viable strategy for improving student's reading skills. Immediately after the treatment, students report that the number of books they read at school in the last week increased from 1.9 to 4.2 and the number of books they read at school in the last month increased from 2.3 to 9.5. At the same time, their reading scores increased by 0.13 standard deviations. Three months after the end of the program, treatment students were still reading 3.1 books more in the last month than the control group. The treatment effect on reading scores also persisted with an effect of 0.06 standard deviations three months later. The program also seems to increase the number of books read outside of school and after the program ended. However, the observed effect is smaller. The effects at the second survey, for example, were an additional 0.34 books read in the last week and 0.89 books read in the last month in school. Breaking down the effect on test scores by subject, the program seems to have its largest and most persistent effect on word recognition, although it has generally positive effects on most of the evaluated elements of the reading exam. 
This study relates to two main strands of the economics of education and education literature. The first involves interventions targeted at improving the reading abilities of young children. A large number of programs in the United States have focused on providing children with one-on-one or small group tutoring in reading, specifically those children identified as requiring remedial attention ${ }^{2}$. Overall, there is some evidence from randomized evaluations that such programs can be effective in improving students' reading skills. Vellutino and Scanlon (2001) randomly assign poor readers to early one-on-one tutoring. The intervention proved effective, and while one-on-one tutoring of all children may prove too costly, the results demonstrate that reading interventions can be effective.

Several programs have evaluated reading programs in the developing context. In India, Banerjee et al. (2007) find that low-cost remedial programs using young women from local communities to teach basic literacy skills to young children substantially improves their performance on a language test. In addition, He, Linden, and MacLeod (2009) find that an Indian program designed to improve the teaching of reading to kindergarten and first grade students can be effective in a number of settings including public schools. Borkum, He and Linden (2009) evaluate a program that provides schools in Bangalore with libraries and find no measurable effects on students' language skills.

Within this strand of literature, attention has also been given to the use of computers, the differences between in- or out-of-school classes, and the involvement of parents and

\footnotetext{
${ }^{2}$ Wassik and Slavin (1993) provide a review of several studies of programs that use trained professionals to conduct various reading and literacy related activities with these children. One particular program that has been extensively evaluated is the Reading Recovery program: see for example Center et al. (1995) and Shanahan and Barr (1995). Wassik (1998) reviews similar studies on programs that use adult volunteers instead, while Baker, Gersten and Keating (2000) conduct a more recent randomized evaluation of such a volunteer tutoring program.
} 
teachers. Rouse and Kruger's (2004) evaluation of a set of instructional computer games known as Fast Forward in the United States finds that these costly interventions (in terms of licenses and equipment) have little impact on general reading ability although they do lead to improved phonetic skills. Machin and McNally (2008) evaluate an in-class literacy program in English primary schools in which one hour per day is set aside for literacy-related activities such as group reading. The authors show that the program had a significant effect on reading and English scores, and that the literacy program even had a lasting impact on students' English scores once they reach secondary school. Finally, Kim (2007) evaluates a program in the United States in which randomly selected children in grades 1-5 received story books over the summer vacation. While self-reported reading activity and participation in literacy-related activities (such as visiting the library) were higher in the treatment group, there were no improvements in reading test scores. Kim suggests a need for more explicit involvement by teachers and parents that goes beyond the mere provision of reading materials.

The second strand of literature to which this study relates seeks to understand more generally the effects of school resources on student learning. Hanushek $(1995,2006)$ reviews a wide range of studies that view resources as inputs in a school production function and test scores as the output. "Resources" in this context are defined broadly and include expenditure per pupil, class size, teacher level of education, material inputs, etc. Hanushek concludes that the evidence that resources matter is weak for both the United States and for developing countries, and he suggests that increasing resources in inefficient school systems is unlikely to improve student outcomes. However, he also suggests that additional resources can make a difference in developing countries where the initial level of resources is particularly low. 
Glewwe and Kremer's (2006) review of education in developing countries provides a detailed assessment of several retrospective studies on developing countries. They conclude that the impact of school and teacher characteristics on student test scores is mostly insignificant. Overall, the more convincing estimates from these evaluations imply that the success of any particular input-based educational intervention in developing countries largely depends on the characteristics of the program itself, and its ability to operate effectively in spite of the problems inherent in the education systems of these countries. For example, Glewwe, Kremer and Moulin's (2007) study of textbooks and Glewwe et al.'s (2004) study of flip charts, both in Kenya, find these resources have little overall impact on test scores. Programs that both provide resources and make a substantive change to the existing pedagogy (e.g. Banerjee et al, 2007, and He, Linden, and MacLeod, 2009), however, do seem to have significant effects.

The remainder of the paper is organized as follows. Section II provides an overview of the intervention. We describe the research design in Section III. Section IV documents the internal validity of the study, and in Section $\mathrm{V}$, we estimate the effects of the treatment. Finally, we conclude in Section VI. 


\section{The Sa Aklat Sisikat Read-A-Thon}

The reading program evaluated in this study is a core program of Sa Aklat Sisikat ${ }^{3}$ (SAS), a non-profit organization located in Metro Manila with the stated goal of building a nation of readers. Since the inception of the organization in 1999, SAS has implemented its reading program in over 750 public schools in every province in the Philippines, reaching nearly 150,000 students. The main focus of the SAS program is to encourage children to read by making it engaging. The program has two main components - providing schools with a set of ageappropriate books and training teachers to carry out a 31 day "read-a-thon" in which students are encourage to read a large number of the books. The program is targeted at fourth grade students because this is the point at which the Philippine school system expects students to have developed sufficient reading fluency to enjoy reading independently. ${ }^{4}$

Because most public schools lack age-appropriate literature, ${ }^{5}$ SAS donates 60 Filipino storybooks to every fourth-grade classroom at participating schools. The books are specifically selected for literary value as well as their potential appeal to students. Books are provided in both of the country's official languages, English and Filipino, so that teachers can use books that match their chosen language of instruction. ${ }^{6}$

\footnotetext{
${ }^{3}$ Sa Aklat Sisikat is loosely translated as "Books Make You Cool."

${ }^{4}$ Reading fluency is the point at which beginning readers rely less on the phonemic decoding to recognize individual words and begin to recognize whole words, allowing for an increase in reading speed and comprehension. Meyer and Felton (1999), for example, define fluency as "the ability to read connected text rapidly, smoothly, effortlessly, and automatically with little conscious attention to the mechanics of reading, such as decoding."

${ }^{5}$ For example, during our visits to local schools, we observed a few schools with libraries. However, most of the books were donated from developed countries. The subjects and writing styles were not age appropriate. It was thus not a surprise that teachers used them infrequently.

${ }^{6}$ For this reason, all evaluations in this study were conducted in Filipino. The Philippines has two official languages, Filipino and English, and under an existing executive order, schools are allowed to instruct students in either language. Books are provided in both languages, although in the sample, students were instructed mainly in Filipino.
} 
Prior to receiving the materials, fourth-grade teachers from each school attend a twoday SAS training session in which they are taught to implement the read-a-thon. Reading specialists at the training workshop also provide the teachers with ideas for various reading lessons that are both interactive and engaging for students. For 31 days after the teachers finish the training, they implement the program. During this period, the students and teachers use the donated storybooks in hour-long daily reading activities including dramatic storytelling, literary games, and individual silent reading. Students are encouraged to read as many of the 60 story books as possible, and each student keeps track of the number of books she reads using an SAS supplied wall chart. Students also write their thoughts about the stories in reading notebooks. Finally, SAS also supports teachers by providing monitors who visit the schools to check that the program is being implemented correctly and to answer any questions that teachers may have.

While the read-a-thon itself only lasts 31 days, the partner schools keep the 60 storybooks following the completion of the program. The books are left for the school to use at their discretion, but the expectation is that the experiences created by the intensive read-athon will encourage teachers to continue using the books in their classes and students to continue reading. 


\section{Methodology}

In order to isolate the causal impact of the reading program, we randomly assigned participation in the program to a subset of public schools. This random assignment of schools into treatment and control groups ensures that receipt of the reading program is statistically uncorrelated with school or student characteristics that may be correlated with students' reading ability. Thus, any differences in reading outcomes across schools following the treatment can be directly attributed to the reading program.

\section{A. Research Design}

The research sample consists of all fourth-grade classrooms at 100 elementary schools in Tarlac province in the Philippines. Prior to the experiment, Sa Aklat Sisikat had never conducted its reading program in the province ${ }^{7}$. In conjunction with the province superintendent, SAS selected nine geographically proximate districts in the province representing a broad range of academic performance levels. From these districts, 100 schools were chosen for the experiment; for most districts, all schools in the district were included in the study.

A baseline survey was conducted in all 100 schools in July 2009. Following the survey, schools were assigned to the treatment and control groups using a matched-pair stratified randomization. Schools were divided into pairs within each district using the school level

\footnotetext{
${ }^{7}$ In addition to the fact that SAS itself had never implemented its reading program in schools in Tarlac province, relatively few other reading interventions had been conducted in the province. Due to a concern that schools in Tarlac City, the largest urban area in Tarlac province, have been previous recipients of other reading programs, schools in Tarlac City were excluded from the sample.
} 
average baseline reading scores. ${ }^{8}$ Within each pair, one school was assigned to the treatment group and the other the control group, resulting in an equal probability of assignment to either group. The read-a-thon was then conducted between the months of September and November. ${ }^{9}$ Two follow-up surveys were conducted to assess the effects of the intervention. The first was conducted immediately after the implementation of the read-a-thon in late November and early December 2009 to measure the immediate effects of the intervention. and the second was conducted in late February 2010 to determine whether the effects persisted after SAS ceased interacting with the treatment schools.

\section{B. Data}

Each survey round contained an assessment of children's reading skills. These exams were based in part on a national reading examination created and administered annually by the Philippine Department of Education. ${ }^{10}$ The examination consisted of a silent reading component and an oral reading component. In the first part of the test, students are asked to silently read a written passage and answer questions relating to the passage. Following the silent reading, students were given a one-on-one oral reading test consisting of letter recognition, sound recognition, word recognition, and an oral reading passage. For each

\footnotetext{
${ }^{8}$ We have also estimated the primary specifications including fixed effects for the original groupings for the randomization. The results are consistent with those presented below. These results are available upon request.

${ }^{9}$ During the implementation of the read-a-thon, Tarlac experienced severe flooding that led to the cancellation of several days of school in many of the school districts. In addition, all-school events such as science fairs, town holidays, and standardized testing caused schools to take days off from the read-a-thon. However, all treatment schools completed the 31 day read-a-thon prior to the first follow-up examination.

${ }^{10}$ We chose to use sections of the national exam in order to ensure that both treatment and control groups were assessed using an instrument with which both groups were equally familiar. We wanted to avoid, for example, choosing an exam that might be geared towards the particular intervention being tested, and thus might favor the treatment students simply due to familiarity. The letter, sound, and word recognition sections were added to assess more basic competencies than typically tested on the official exam.
} 
section, we created a standardized score by normalizing relative to the control distribution. Because the values for each section are not measured using the same units, we create a composite normalized reading score by averaging the normalized scores from each section and then normalizing the average, again relative to the distribution of the control group.

A local survey firm proctored and graded all of the examinations independently of the teachers to guarantee the validity of the test scores. In addition, teachers were not informed in advance of the content of the exam to prevent them from preparing students for the test. In order to ensure that a high percentage of students in the sample were tested, the survey team returned multiple times to many of the schools to test absent students.

Each survey also contained data unique to the individual round. In the baseline survey, we collected children's age, gender, height, weight, number of siblings, religion, and the dialect spoken at home. In the follow-up surveys, we collected information on children's reading habits as well as tested students in other subjects to investigate possible spillovers from the intervention. The reading survey asked students about the number of books they read in the last week and the last month both in and out of school. In addition, we asked students to name the title and to describe the plot of the last book they read to assess the validity of their responses. For the alternate subject tests, we tested a different subject each round. In the first follow-up survey, we tested children's math skills, and in the second one, we tested children's knowledge of social studies, the most reading intensive alternate subject. 


\section{Statistical Models}

In order to analyze the effect of the reading program, we utilize three basic models. First, we employ a simple difference specification to directly compare the treatment and control groups:

$$
Y_{\text {is }}=\alpha+\beta_{1} T_{s}+\varepsilon_{\text {is }}
$$

where $Y_{\text {is }}$ is the outcome of interest for child $i$ in school $s$; and $T_{s}$ is an indicator variable for whether the school received the reading program. Hence, the estimate of the coefficient $\beta_{1}$ indicates the differences between treatment and control schools. We utilize this model to compare baseline differences in socio-demographic characteristics and test scores and to estimate the effect of the reading program on follow-up test scores and reading habits.

Since the reading program is randomly assigned to schools and therefore independent of baseline characteristics, inclusion of observable baseline characteristics and baseline test scores as control variables in equation (1) improves the precision of the estimated treatment effect. We also run the following specification:

$$
Y_{\text {is }}=\alpha+\beta_{1} T_{s}+\beta_{2} X_{i s}+\omega_{d}+\varepsilon_{\text {is }}
$$

where $Y_{\text {is }}$ and $T_{s}$ are defined as in equation (1), and where $X_{\text {is }}$ is a vector of baseline student characteristics including composite baseline reading test score, gender, age, religion dummies, dialect dummies, and body mass index (BMI). Since randomization was stratified within district, we also include district fixed effects, $\omega_{d}$, in equation (2).

Finally, we test the validity of the experiment by comparing the effect of the treatment on the relative characteristics of the children who attrite from the sample between the baseline survey and the two follow-up surveys. We run the following difference in differences model: 


$$
Y_{\text {is }}=\alpha+\beta_{1} T_{s}+\beta_{2} \text { Attrit }_{\text {is }}+\beta_{3} T_{s} * \text { Attrite }_{\text {is }}+\varepsilon_{\text {is }}
$$

The variables $Y_{\text {is }}$ and $T_{s}$ are defined as before, and Attrite ${ }_{\text {is }}$ is an indicator variable equal to one if a student $i$ enrolled in school $s$ is not present in the follow-up data. The estimate of $\beta_{2}$ then provides the average differences between attritors and non-attritors, and the estimate of $\beta_{3}$ captures the difference between attritors and non-attritors in the treatment group relative to the same difference in the control group.

Because outcomes may be correlated within school, failure to correct the standard errors could result in an overestimate of the precision of the treatment effects (Bertrand, Duflo, Mullainathan, 2004). We therefore cluster the standard errors at the school level (the level of randomization) in all of the above models.

\section{Internal Validity}

Randomly assigning schools to the intervention ensures that assignment is orthogonal to student characteristics that may be correlated with the outcomes of interest. If this holds, then any differences in outcomes between the two groups post-intervention can be causally attributed to the intervention. To check that student characteristics were indeed similar between the two groups, we run regressions of student characteristics from the baseline survey on treatment status, and then verify that changes in the sample due to attrition are also uncorrelated with treatment status.

We present the comparison of students at baseline in Table 1 . Column 1 contains the average characteristics for the control group. Columns 2 and 3 present the estimated differences between the treatment and control groups. The results in column 2 do not include 
any controls, while those in column 3 control for district fixed effects. Panels A and B contain standardized reading test scores and demographic characteristics, respectively.

The differences in average characteristics between the control and treatment groups are all practically small and mostly statistically insignificant. In Panel A, none of the differences in test scores are statistically significant. Figure 1 shows a plot of the distribution of the standardized overall reading test score for the treatment group (dotted line) and the control group (solid line). These distributions almost overlap, further corroborating the comparability of the treatment and control groups. In Panel B, the only demographic variables with statistically significant differences are those related to religion, but these differences are small in magnitude. For instance, 74 percent of students in the control group are Catholics compared to 69 percent in the treatment group, yielding a minimal difference of 5 percentage points. Thus, overall, the randomization appears to have been successful in creating comparable treatment and control groups.

Although the baseline comparisons presented in Table 1 and Figure 1 show that the treatment and control groups were similar at baseline, it is possible that non-random attrition from the two groups between the baseline and follow-up surveys may have rendered the two groups incomparable. Table 2 shows the attrition rates for both groups and the differences between the two. There are no statistically significant differences between the attrition rates for the control and treatment groups. For both groups, approximately 5 percent of the students who were tested during the baseline survey were absent during the first follow-up survey, and 11 percent were absent during the second survey. Comparing the rates across 
research groups, the rates are the same in the first follow-up and differ by only 2 percentage points in the second (10 percentage points in the treatment schools and 12 in the control).

Columns 4 through 6 provide estimates of the attrition rates between follow-up surveys. Overall, 86 percent of the students were present at both follow-up surveys (column 4), and the difference in the rates between research groups is small. Similarly, 91 percent of students who were present at follow-up one were also present at the second follow-up, and of those present at the second, 97 percent were present at the first.

Even though the attrition rates were similar for both groups, the characteristics of the attritors and non-attritors could have still differed between the two groups. We check this possibility in Table 3 for the first follow-up survey. The results for the second follow-up survey are similar and presented in the Appendix (Table A1). Panel A focuses on test scores while Panel B focuses on demographic characteristics. Columns 1 and 2 contain the average characteristic for non-attritors in the control and treatment groups, respectively, while column 3 contains the difference between these averages estimated using equation (1). All of the differences are statistically insignificant with the exception of the proportion of non-attritors who are Catholic. However, this difference is small in magnitude (5 percentage points) and is identical to the difference found for the entire sample during the baseline survey.

The last three columns of Table 3 show that the differences between the characteristics of the non-attritors and attritors are similar across the two groups. Column 4 presents the difference in average characteristic between the non-attritors and the attritors in the control group. Column 5 presents this same statistic for the treatment group, and column 6 presents the difference between the two statistics using equation (3). These differences are mostly 
statistically insignificant, and all of them are small in magnitude. We therefore conclude that the comparability of the control and treatment groups was sustained throughout the follow-up surveys.

\section{Results}

Given that the research groups are comparable, we can attribute any differences in outcomes observed in the follow-up surveys to the intervention. SAS aims to promote the habit of reading in students and, thereby, improve their reading ability. We therefore proceed with our analysis of the outcomes as follows. We first investigate whether the intervention was successful in promoting the habit of reading in students by comparing the frequency of reading between the control and treatment groups. We then determine whether the observed positive effect of the intervention on reading habits translated into improvements in students' reading ability by comparing students' test scores.

\section{A. Effect on Reading Habits}

Table 4 compares reading rates across the two groups based on survey responses during the first and second follow-up surveys. Variables included in the table are students' responses to questions on whether or not they had read a book and the number of books read in different timeframes. To check that students who claim to have read a book actually did so, students were also asked to give the name of and describe the last book they had read. The responses to these questions are also included in Table 4. 
The first three columns report results from the first follow-up survey, while the last three columns report results from the second follow-up survey. Panel A contains responses to survey questions on reading in school, and Panel B contains responses to survey questions on reading outside school. The first column for each of the follow-up surveys provides the average responses for the control group, while the second column provides estimates of the differences between the average responses of the control and treatment groups (equation (1)). The third column for each of the follow-up surveys reports estimates of these differences that control for district fixed effects and demographic characteristics (equation (2)).

The program had large and statistically significant impacts on the reading habits of students. The results in columns 1 and 3 of Table 4 show that during the first follow-up survey 68 percent of the students in the control group reported reading a book in school in the past week, and the program increased this by 19 percentage points. The students in the control group reported reading an average of 1.9 books in school in the past week and the program increases this by 2.3 books. In the past month, the program increased the number of books read by 7.2 books.

Further corroborating these results, ${ }^{11}$ we find significant differences in the propensity to read if we only consider a child as having read a book if he or she can provide specific information about the last book read. If we consider children to have read a book only if they

\footnotetext{
${ }^{11}$ One of the concerns with these self-reported numbers was that, knowing that they are generally expected to read, students might lie to surveyors about having read a book recently. The additional questions about the books provide one check. Also interesting in this respect, is the stability of the estimates for the fraction of children having reported reading a book (and being able to provide title and description) across the various surveys. For the control students, for example, the largest differences in rates is for the fraction of students reporting reading a book and being able to describe the book in Panel A at 9 percentage points. The next largest difference is 6 percentage points (being able to give the title and reporting having read a book in Panel A). The other five differences between the surveys are all in the range of 2-3 percentage points.
} 
claim to have read a book and can provide the title, 53 percent of students in the control group read a book in the last week and the increase due to the program was 30 percentage points. If the condition is to describe the plot, the program caused 23 percentage points more children to have read a book. All of these results are statistically significant at the one percent level and are basically the same for the different specifications presented in columns 2 and 3.

The results for reading habits in school from the second follow-up survey are presented in the last three columns of Table 4. They show that while the propensity to read seems to remain stable, the intensity of reading behavior, while still increased due to the program, is smaller after the 31-day intensive program. When asked if they had read any book in the last week, the program caused 22 percentage points more children to respond affirmatively. However, when we focus on the actual number of books read, the effects are smaller. The effect for the last week is 0.9 additional books in our preferred specification which controls for demographic characteristics and district fixed effects (and not statistically significant at conventional levels) while the effect in the last month is 3.1 books and statistically significant at the 1 percent level. This suggests that the students introduced to books through the program are still more likely to read at school, but the number of books they read understandably declines when the incentives present in the read-a-thon are removed.

If the program interests children in reading, we might also expect them to read more outside of school. ${ }^{12}$ The results for reading outside school are presented in Panel B of Table 4. Overall, the program does increase the propensity to read, even outside of school. However, it

\footnotetext{
${ }^{12}$ Teachers tend to value the books provided by SAS highly. As a result, almost no teachers allow children to take the books home to read for fear that the children might lose them. Thus, for children to read at home, they must have accessed books independently of the intervention.
} 
does so at a lower rate than in school. For the propensity to read at all, the effects of the program are small. For children claiming to have read a book in the last week, there is no difference between the treatment and control groups (row 1). However, when we condition on children being able to provide additional information on the last book read outside of school (rows 4 and 5), we find that the program seems to have had a small effect of 2 to 7 percentage points - differences that are significant in the second follow-up but not the first.

The effect outside of school seems to operate by increasing moderately the number of books read by children who read outside of school. The number of books read in the last month increases by 1.2 books in the first survey and 0.9 in the second - both statistically significant at the one percent level. In the last week, the effect is the same in both periods $(0.4$ in the first follow-up and 0.3 in the second), but only statistically significant in the second period at the one percent level.

\section{B. Effect on Reading Ability}

We now explore the extent to which the changes in reading habits affected students' reading ability. Table 5 presents estimates of the differences between the standardized average test scores of the control and treatment groups. The estimates in column 1 do not control for any variables and are estimated using equation (1). The estimates in column 2 control for demographic characteristics while those in column 3 control for these demographic characteristics in addition to district fixed effects using equation (2).

Starting with the results from the first follow-up survey in Panel A, the data show that the program had a distinct immediate effect on students' reading skills of 0.13 standard 
deviations. The results are consistent across the various specifications, highlighting the comparability of the treatment and control groups. And, in our preferred specification, the results are statistically significant at the one percent level. We also tested students' math skills to assess possible spillovers from the program - either negative due to the read-a-thon crowding out instructional time for other subjects or positive due to students' increased ability to read the text books. However, while the observed treatment effects on math scores are positive, they are small and statistically insignificant.

At 0.13 standard deviations, the direct effect of the program is consistent with the effects of many programs on native language skills. ${ }^{13}$ Machin and McNally (2008), Muralidharan and Sundararaman (2011), Muralidharan and Sundararaman (2010), and Das et al. (2010) find effects in this range, for example. This is, however, smaller than the effects observed for others. Banerjee et al. $(2007)^{14}$ find a total effect of 0.187 standard deviations immediately after two years of implementation and He, Linden, and MacLeod (2009) find a one year effect of 0.695 standard deviations for the pre-school program after a year of implementation.

One can also take into account the costs of the program. However, it is important to keep two caveats in mind. First, this program only affects reading skills while many of the other programs are designed to affect directly multiple subjects. Second, the number of studies reporting treatment effects for native language skills as well as information on program costs is rather small. With these caveats in mind, the SAS reading program seems to fall in the midrange of programs adjusting for cost. The cost per tenth of a standard deviation gain per child is

\footnotetext{
${ }^{13}$ Typically, the effects of such programs are much lower than the effects observed in other subjects, such as math and foreign languages (see Banerjee et al. (2007) for example).

${ }^{14}$ Banerjee et al. (2007) evaluate two programs, a computer assisted learning program focused on math and a remedial education program focused on all subjects. Here we refer only to the remedial education program.
} 
8.52 USD. $^{15}$ This is higher than the interventions considered by Banerjee et al (2007), Muralidharan and Sundararaman (2011), Muralidharan and Sundararaman (2010), and Das et al. (2011), all of which cost between 1.53 USD and 3.11 USD per tenth a standard deviation per child for native language skills in India. It is, however, much lower than Machin and McNally (2009) whose UK-based program costs $\$ 46.42$ USD per tenth of a standard deviation per child. ${ }^{16}$

The results from the second follow-up survey demonstrate the improvements in reading skills persist beyond the program implementation period, but at a smaller level. In Panel B of Table 5, the estimates of the difference between the average reading score of the treatment and control groups range from 0.06 to 0.08 standard deviations with an effect of 0.06 in our preferred specification (significant at the five percent level). On the second survey, we tested children's knowledge of social studies rather than math, but still cannot detect statistically significant positive or negative spillovers. In this case, however, the treatment effect is of the same magnitude as for the reading test, but measured less precisely. ${ }^{17}$

We also investigate differences in the observed treatment effects for a number of subsets of our sample defined through the baseline survey. In results not presented in this manuscript, ${ }^{18}$ we test for differences in treatment effects by gender, age, language spoken at home, and baseline reading score. We find almost no evidence of systematically different treatment effects for different types of students for either follow-up period. The one exception is that we find that, for the first follow-up period, the treatment effect increases with students'

\footnotetext{
${ }^{15}$ All cost information has been adjusted to 2010 USD using the US Consumer Price Index for All Urban Consumers including all available items.

${ }^{16}$ India, Philippines, and the UK are, of course, very different countries, making it difficult to rank programs based solely on this measure of cost-effectiveness. However, since there are so few examples of successful reading programs that report such cost information, we present those that we have found.

${ }^{17}$ This may be due to the fact that the social studies test was much less comprehensive than the reading test.

${ }^{18}$ Results are available upon request.
} 
baseline test score. In a regression interacting treatment effect with baseline score, we find that students experience a 0.12 standard deviation increase independent of their baseline scores (statistically significant at the one percent level) and then experience an increased effect of 0.09 standard deviations for each additional standard deviation they scored at baseline (significant at the ten percent level). While both coefficients are still positive at the second follow-up the magnitudes are much smaller $(0.06$ for the direct effect and 0.04 for the interaction effect) and only the direct effect remains statistically significant at conventional levels (five percent level).

\section{Effects by Test Component}

Disaggregating the results, Table 6 provides the results for each component of the reading test in addition to the overall average reading test score. The first two columns report the results from the first follow-up survey, while the last two columns report the results from the second follow-up survey. The first column for each of the follow-up surveys provides the differences between the average test scores of the control and treatment groups using equation (1). The second column provides the estimates with the full set of controls using equation (2). Finally, the last two rows of Table 6 report the chi-squared statistic and p-value from a test of the joint significance of the coefficients on the treatment indicator from the regressions for the individual components of the reading test. These coefficients are estimated in a system of seemingly unrelated regression equations.

From the results in Table 6, it appears that in both the first and second follow-up surveys, the program had a generally positive effect on most of the components on the test 
(the written part being the one exception). In the first follow-up survey, there are sizable treatment effects on sound recognition, word recognition, and the ability to answer questions from the oral reading passage. Of these, the effects on word recognition and oral questions are individually statistically significant at the one and ten percent levels respectively, and the effect on sound recognition is not statistically significant at conventional levels. The joint test of an effect on all skills shows that the results for the different components are jointly statistically significant with a $p$-value of 0.013 .

In the second follow-up, the results are generally the same, but as with the overall average, diminished in magnitude. In this round, word recognition and oral reading effects are individually statistically significant with word recognition remaining the strongest effect of the program. But again, all components show positive treatment effects except the written test and sound recognition. Overall, the joint hypothesis of the significance of the effects on each component is still statistically significant at the one percent level. 


\section{Conclusion}

The results of this paper demonstrate that a short-term reading program that encourages students to read age-appropriate material can have a significant effect on the reading ability of primary school children. We show that providing fourth-grade students with age-appropriate books and training teachers to encourage reading for 31 days through the use

of daily reading activities succeeded in improving students' reading habits and skills. Reading test scores of students increased by 0.13 of a standard deviation immediately following the intervention. These gains in reading ability were still evident, albeit smaller at about 0.06 standard deviations, three months after the end of the intervention. Implementing such shortterm programs that promote reading can therefore be an effective way of cultivating good sustainable reading habits in children and improving their reading ability. 


\section{Bibliography}

Baker, S., Gersten, R. and Keating, T. (2000) "When Less May Be More: A 2-Year Longitudinal Evaluation of a Volunteer Tutoring Program Requiring Minimal Training," Reading Research Quarterly. 35(4): 494-519.

Banerjee, A., Cole, S., Duflo, E. and Linden, L. (2007) "Remedying Education: Evidence from Two Randomized Experiments in India," Quarterly Journal of Economics. 122(3): 1235-1264.

Bertrand, M., Duflo, E. and Mullainathan, S. (2004) "How Much Should We Trust Difference-inDifferences Estimates?," Quarterly Journal of Economics. 119(1): 249-275.

Borkum, E., He, F. and Linden, L. (2009). "School Libraries and Language Skills in Indian Primary Schools: A Randomized Evaluation of the Akshara Library Program," Working paper. Department of Economics. The University of Texas at Austin.

Center, Y., Wheldall, K., Freeman, L., Outhred, L. and McNaught, M. (1995) "An Evaluation of Reading Recovery," Reading Research Quarterly. 30(2): 240-263.

Das, Jishnu et. Al (2011) "School Inputs, Household Substitution, and Test Scores," Working Paper. Department of Economics. The University of California at San Diego.

Glewwe, P. and Kremer, M. (2006) "Schools, Teachers and Education Outcomes in Developing Countries," in Hanushek, A. and Welch, F. (eds.): Handbook of the Economics of Education (vol. 2). Amsterdam: Elsevier.

Glewwe, P., Kremer, M., Moulin, S. and Zitzewitz, E. (2004) "Retrospective vs. Prospective Analyses of School Inputs: The Case of Flip Charts in Kenya," Journal of Development Economics. 74:251-286.

Glewwe, P., Kremer, M. and Moulin, S. (2009) "Many Children Left Behind? Textbooks and Test Scores in Kenya," American Economic Journal: Applied Economics. 1(1): 112-135.

Hanushek, E. (1995) "Interpreting Recent Research on Schooling in Developing Countries," World Bank Research Observer. 10(2): 227-246.

Hanushek, E. (2006) "School Resources," in Hanushek, A. and Welch, F. (eds.): Handbook of the Economics of Education (vol. 2) Amsterdam: Elsevier.

Hanushek, E. and Wossman, L. (2007) The Role of Education Quality for Economic Growth. Washington, DC: World Bank.

He, F., Linden, L. and MacLeod, M. (2008) "Teaching What Teachers Don't Know: An Assessment of the Pratham English Language Program," Working Paper. Department of Economics. The University of Texas at Austin. 
He, F., Linden, L. and MacLeod, M. (2009) "Teaching Pre-Schoolers to Read: A Randomized Evaluation of the Pratham Shishuvachan Program," Working Paper. Department of Economics. The University of Texas at Austin.

Kim, B.S. (2007) "The Effects of a Voluntary Summer Reading Intervention on Reading Activities and Reading Achievement," Journal of Educational Psychology. 99(3): 505-515.

Machin, S. and McNally, S. (2009) "The Literacy Hour," Journal of Public Economics. 92:1441-62.

Meyer, Marianne S. and Rebecca H Felton. (1999) "Repeating Reading to Enhance Fluency: Old Approaches and New Directions," Annals of Dyslexia. 49:283-306.

Muralidharan, Karthik and Venkatesh Sundararaman (2010) "Contract Teachers: Experimental Evidence from India," Working Paper. Department of Economics. The University of California at San Diego.

Muralidharan, Karthik and Venkatesh Sundararaman (2011) "Teacher Performance Pay: Experimental Evidence from India," Journal of Political Economy, 119(1): 39-77

Rouse, C.E. and Krueger, A.B. (2004) "Putting Computerized Instruction To The Test: A Randomized Evaluation of a 'Scientifically-Based' Reading Program," Economics of Education Review. 23(4): 323-338; 2004.

Scarborough, H.S. (2001) "Connecting Early Language and Literacy to Later Reading (Dis)Abilities: Evidence, Theory, and Practice," In S.B. Neuman and D.K. Dickinson (Eds.), Handbook of Early Literacy Research (Volume 1) (pp. 97-110). New York, NY: Guilford Press.

Shanahan, T. and Barr, R. (1995) "Reading Recovery: An Independent Evaluation of the Effects of an Early Instructional Intervention for At-Risk Learners," Reading Research Quarterly. 30(4): 958-996.

Vellutino, F.R. and Scanlon, D.M. (2001) "Emergent literacy skills, early instruction, and individual differences as determinants of difficulties in learning to read: The case for early intervention," In S.B. Neuman and D.K. Dickinson (Eds.), Handbook of Early Literacy Research (Volume 1) (pp. 295-321). New York, NY: Guilford Press.

Wasik, B.A. (1998) "Volunteer Tutoring Programs in Reading: A Review," Reading Research Quarterly. 33(3): 266-291.

Wasik, B.A. and Slavin, E. (1993) "Preventing Early Reading Failure with One-to-One Tutoring: A Review of Five Programs," Reading Research Quarterly. 28(2): 178-200. 
Figure 1: Kernel Density Estimates of Baseline Reading Scores

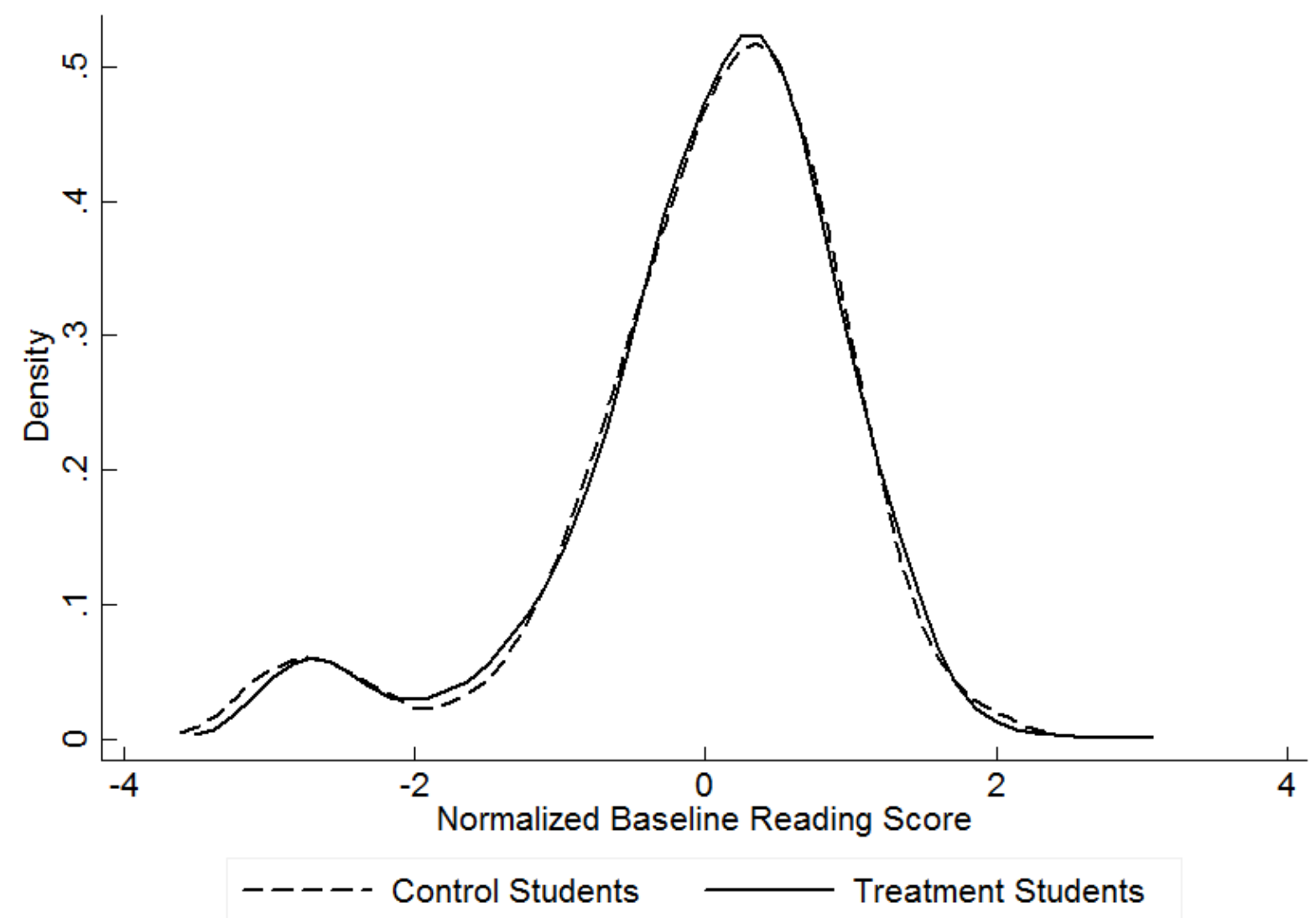

Note: This figure presents kernel density estimates of the baseline total normalized reading score distributions for the treatment and control groups. Distributions estimated using an Epanechnikov kernel with a bandwidth of 0.2 standard deviations. 
Table 1: Baseline Comparisons

\begin{tabular}{cccc} 
& Control & Treatment Difference & Treatment Difference \\
Dependent Variable & Mean & No Controls & District FE \\
& $(1)$ & $(2)$ & $(3)$ \\
\hline \hline
\end{tabular}

Panel A: Standardized Baseline Reading Test Scores

$\begin{array}{lccc}\text { Written Test } & 0.00 & 0.02 & 0.03 \\ & & (0.05) & (0.04) \\ \text { Letter Recognition } & 0.00 & 0.03 & 0.03 \\ & & (0.04) & (0.04) \\ \text { Sound Recognition } & 0.00 & -0.10 & -0.06 \\ & & (0.07) & (0.07) \\ \text { Word Recognition } & 0.00 & 0.02 & 0.03 \\ & & (0.06) & (0.06) \\ \text { Oral Reading } & 0.00 & 0.02 & 0.04 \\ & & (0.06) & (0.06) \\ \text { Oral Reading Questions } & 0.00 & 0.04 & 0.05 \\ & & (0.07) & (0.05) \\ \text { Average Score } & 0.00 & 0.01 & 0.03 \\ & & (0.06) & (0.06)\end{array}$

Panel B: Individual Characteristics

\begin{tabular}{|c|c|c|c|}
\hline Age & 9.37 & $\begin{array}{l}-0.01 \\
(0.05)\end{array}$ & $\begin{array}{l}-0.01 \\
(0.05)\end{array}$ \\
\hline \multirow[t]{2}{*}{ Female } & 0.48 & -0.01 & -0.01 \\
\hline & & $(0.01)$ & $(0.01)$ \\
\hline \multirow[t]{2}{*}{ Height } & 128.44 & -0.05 & -0.05 \\
\hline & & $(0.32)$ & $(0.26)$ \\
\hline \multirow[t]{2}{*}{ Weight } & 56.56 & 0.83 & 0.57 \\
\hline & & $(0.77)$ & $(0.69)$ \\
\hline \multirow[t]{2}{*}{$\mathrm{BMI}$} & 15.42 & 0.23 & 0.15 \\
\hline & & $(0.17)$ & $(0.16)$ \\
\hline \multirow[t]{2}{*}{ Siblings } & 3.88 & 0.07 & 0.08 \\
\hline & & $(0.11)$ & $(0.09)$ \\
\hline \multirow[t]{2}{*}{ Catholic } & 0.74 & $-0.05^{\star}$ & $-0.05^{* *}$ \\
\hline & & $(0.03)$ & $(0.02)$ \\
\hline \multirow[t]{2}{*}{ INC } & 0.13 & 0.01 & 0.01 \\
\hline & & $(0.01)$ & $(0.01)$ \\
\hline \multirow[t]{2}{*}{ Aglipayan } & 0.02 & 0.00 & 0.01 \\
\hline & & $(0.01)$ & $(0.01)$ \\
\hline \multirow[t]{2}{*}{ Born Again } & 0.06 & 0.02 & $0.02^{\star}$ \\
\hline & & $(0.01)$ & $(0.01)$ \\
\hline \multirow[t]{2}{*}{ Protestant } & 0.02 & 0.01 & 0.01 \\
\hline & & $(0.01)$ & $(0.01)$ \\
\hline \multirow[t]{2}{*}{ Other Religion } & 0.02 & 0.01 & 0.00 \\
\hline & & $(0.01)$ & $(0.00)$ \\
\hline \multirow[t]{2}{*}{ Filipino } & 0.44 & 0.01 & 0.01 \\
\hline & & $(0.07)$ & $(0.04)$ \\
\hline \multirow[t]{2}{*}{ lloco } & 0.19 & -0.05 & -0.03 \\
\hline & & $(0.05)$ & $(0.03)$ \\
\hline \multirow{2}{*}{ Kapampangan } & 0.37 & 0.04 & 0.02 \\
\hline & & $(0.09)$ & $(0.03)$ \\
\hline \multirow[t]{2}{*}{ Pangasinan } & 0.01 & $<0.01$ & $<0.01$ \\
\hline & & $(<0.01)$ & $(<0.01)$ \\
\hline \multirow[t]{2}{*}{ Other Language } & $<0.01$ & $<0.01$ & $<0.01$ \\
\hline & & $(<0.01)$ & $(<0.01)$ \\
\hline Dbservations & 2596 & 5510 & 5510 \\
\hline
\end{tabular}


Table 2: Overall Attrition

\begin{tabular}{l}
$\begin{array}{l}\text { No. of Students } \\
\text { at Baseline }\end{array}$ \\
\cline { 3 - 6 }
\end{tabular}


Table 3: Attrition Patterns - Follow-Up One

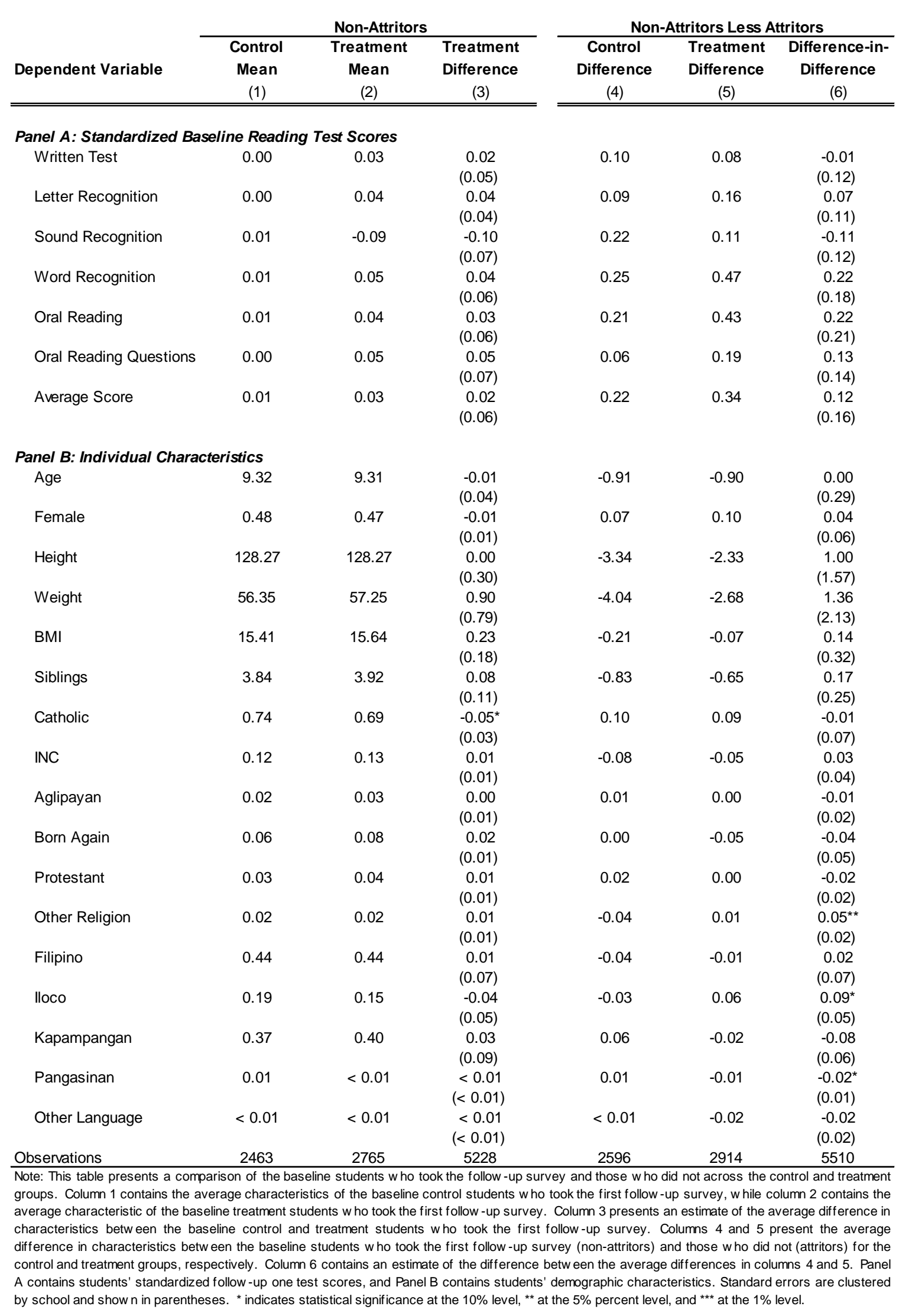


Follow-Up One

\begin{tabular}{|c|c|c|c|c|c|c|}
\hline \multirow[b]{2}{*}{ Dependent Variable } & \multicolumn{3}{|c|}{ Follow-Up One } & \multicolumn{3}{|c|}{ Follow-Up Two } \\
\hline & $\begin{array}{l}\text { Control } \\
\text { Mean } \\
(1)\end{array}$ & $\begin{array}{c}\text { Treatment Difference } \\
\text { No Controls } \\
(2)\end{array}$ & $\begin{array}{c}\text { Treatment Difference } \\
\text { District FE and Controls } \\
\text { (3) }\end{array}$ & $\begin{array}{l}\text { Control } \\
\text { Mean } \\
(4)\end{array}$ & $\begin{array}{c}\text { Treatment Difference } \\
\text { No Controls } \\
\text { (5) }\end{array}$ & $\begin{array}{l}\text { Treatment Difference } \\
\text { District FE and Controls } \\
\text { (6) }\end{array}$ \\
\hline Panel A: Survey Responses to Reading Books in School & & & & & & \\
\hline did you read any book (excluding textbooks) in the last week in school? & 0.68 & $\begin{array}{l}0.18^{\star \star \star} \\
(0.03)\end{array}$ & $\begin{array}{l}0.19^{\star \star \star} \\
(0.03)\end{array}$ & 0.51 & $\begin{array}{l}0.22^{\star \star \star} \\
(0.04)\end{array}$ & $\begin{array}{l}0.22^{\star \star \star} \\
(0.04)\end{array}$ \\
\hline no. of books (excluding textbooks) read in the last week in school & 1.85 & $\begin{array}{l}2.35^{\star \star \star} \\
(0.52)\end{array}$ & $\begin{array}{l}2.33^{\star \star \star} \\
(0.56)\end{array}$ & 1.34 & $\begin{array}{l}0.98^{\star \star} \\
(0.49)\end{array}$ & $\begin{array}{r}0.86 \\
(0.53)\end{array}$ \\
\hline no. of books (excluding textbooks) read in the last month in school & 2.32 & $\begin{array}{l}7.41^{\star \star \star} \\
(0.88)\end{array}$ & $\begin{array}{l}7.17^{\star \star \star} \\
(0.82)\end{array}$ & 1.54 & $\begin{array}{l}3.32^{\star \star \star} \\
(0.56)\end{array}$ & $\begin{array}{l}3.12^{\star \star \star} \\
(0.42)\end{array}$ \\
\hline student able to give name of last book read in school? & 0.53 & $\begin{array}{l}0.29^{\star \star \star} \\
(0.04)\end{array}$ & $\begin{array}{l}0.30^{\star \star \star} \\
(0.03)\end{array}$ & 0.47 & $\begin{array}{l}0.26^{\star \star \star} \\
(0.04)\end{array}$ & $\begin{array}{l}0.26^{\star \star \star} \\
(0.03)\end{array}$ \\
\hline student able to describe last book read in school? & 0.55 & $\begin{array}{l}0.22^{\star \star *} \\
(0.04)\end{array}$ & $\begin{array}{l}0.23^{\star * *} \\
(0.03)\end{array}$ & 0.46 & $\begin{array}{l}0.23^{\star \star \star} \\
(0.04)\end{array}$ & $\begin{array}{l}0.23^{\star \star *} \\
(0.03)\end{array}$ \\
\hline Panel B: Survey Responses to Reading Books Outside School & & & & & & \\
\hline did you read any book (excluding textbooks) in the last week outside school? & 0.48 & $\begin{array}{l}<0.01 \\
(0.04)\end{array}$ & $\begin{array}{c}0.01 \\
(0.04)\end{array}$ & 0.45 & $\begin{array}{c}0.01 \\
(0.04)\end{array}$ & $\begin{array}{c}0.01 \\
(0.03)\end{array}$ \\
\hline no. of books (excluding textbooks) read in the last week outside school & 1.40 & $\begin{array}{c}0.18 \\
(0.43)\end{array}$ & $\begin{array}{c}0.36 \\
(0.28)\end{array}$ & 0.77 & $\begin{array}{l}0.35^{\star \star \star} \\
(0.11)\end{array}$ & $\begin{array}{l}0.34^{\star \star \star} \\
(0.09)\end{array}$ \\
\hline no. of books (excluding textbooks) read in the last month outside school & 1.61 & $\begin{array}{l}1.28^{\star \star \star} \\
(0.30)\end{array}$ & $\begin{array}{l}1.24^{\star \star \star} \\
(0.25)\end{array}$ & 1.20 & $\begin{array}{l}0.92^{\star \star \star} \\
(0.18)\end{array}$ & $\begin{array}{l}0.89^{\star \star \star} \\
(0.16)\end{array}$ \\
\hline student able to give name of last book read outside school? & 0.38 & $\begin{array}{c}0.03 \\
(0.04)\end{array}$ & $\begin{array}{c}0.04 \\
(0.03)\end{array}$ & 0.36 & $\begin{array}{l}0.08^{\star \star} \\
(0.03)\end{array}$ & $\begin{array}{l}0.07^{\star \star} \\
(0.03)\end{array}$ \\
\hline student able to describe last book read outside school? & 0.39 & $\begin{array}{r}0.01 \\
(0.04)\end{array}$ & $\begin{array}{c}0.02 \\
(0.03)\end{array}$ & 0.37 & $\begin{array}{l}0.06^{\star} \\
(0.04)\end{array}$ & $\begin{array}{l}0.06^{\star} \\
(0.03)\end{array}$ \\
\hline
\end{tabular}


Table 5: Effects on Test Scores

\begin{tabular}{|c|c|c|c|}
\hline Dependent Variable & $\begin{array}{c}\text { Treatment Difference } \\
\text { No Controls } \\
(1) \\
\end{array}$ & $\begin{array}{c}\text { Treatment Difference } \\
\text { Controls } \\
(2) \\
\end{array}$ & $\begin{array}{r}\text { Treatment Diffe } \\
\text { District FE and } \\
(3) \\
\end{array}$ \\
\hline \multicolumn{4}{|c|}{ Panel A: Standardized Follow-Up One Test Scores } \\
\hline \multirow[t]{2}{*}{ Average Reading Score } & $0.13^{\star}$ & $0.12^{\star \star}$ & $0.13^{\star \star \star}$ \\
\hline & $(0.07)$ & $(0.05)$ & $(0.05)$ \\
\hline \multirow[t]{2}{*}{ Average Math Score } & 0.04 & 0.04 & 0.03 \\
\hline & $(0.07)$ & $(0.05)$ & $(0.05)$ \\
\hline \multicolumn{4}{|c|}{ Panel B: Standardized Follow-Up Two Test Scores } \\
\hline \multirow[t]{2}{*}{ Average Reading Score } & 0.08 & $0.07^{\star *}$ & $0.06^{\star *}$ \\
\hline & $(0.07)$ & $(0.03)$ & $(0.03)$ \\
\hline \multirow[t]{2}{*}{ Average Social Studies Score } & 0.06 & 0.05 & 0.06 \\
\hline & $(0.06)$ & $(0.05)$ & $(0.06)$ \\
\hline
\end{tabular}

Note: This table displays the estimated effects of the treatment on students' test scores. Column 1 reports an estimate of the difference between the test scores of the control and treatment students. Column 2 reports an estimate of the average difference betw een the test scores of the control and treatment students controlling for demographic characteristics, namely age, gender, body mass index (BMI) (and their interactions), number of siblings, religion, language, and baseline reading score. Column 3 reports an estimate of the average difference between the test scores of the control and treatment students controlling for the aforementioned demographic characteristics and district fixed effects. Panel A presents the results from the first follow-up survey, while Panel B presents the results from the second follow-up survey. Standard errors are clustered by school and show $n$ in parentheses. * indicates statistical significance at the $10 \%$ level, ${ }^{\star \star}$ at the $5 \%$ percent level, and ${ }^{\star \star \star}$ at the $1 \%$ level. 


\begin{tabular}{|c|c|c|c|c|}
\hline Dependent Variable & $\begin{array}{c}\text { Treatment Difference } \\
\text { No Controls } \\
(1)\end{array}$ & $\begin{array}{c}\text { Treatment Difference } \\
\text { District FE and Controls } \\
\text { (2) }\end{array}$ & $\begin{array}{c}\text { Treatment Difference } \\
\text { No Controls } \\
(3) \\
\end{array}$ & $\begin{array}{c}\text { Treatment Difference } \\
\text { District FE and Controls } \\
(4)\end{array}$ \\
\hline Written Test & $\begin{array}{l}-0.02 \\
(0.05)\end{array}$ & $\begin{array}{r}-0.03 \\
(0.04)\end{array}$ & $\begin{array}{l}-0.05 \\
(0.05)\end{array}$ & $\begin{array}{l}-0.06^{*} \\
(0.03)\end{array}$ \\
\hline Letter Recognition & $\begin{array}{r}0.04 \\
(0.05)\end{array}$ & $\begin{array}{r}0.03 \\
(0.05)\end{array}$ & $\begin{array}{c}0.10^{\star} \\
(0.06)\end{array}$ & $\begin{array}{c}0.07 \\
(0.04)\end{array}$ \\
\hline Sound Recognition & $\begin{array}{c}0.12 \\
(0.09)\end{array}$ & $\begin{array}{c}0.12 \\
(0.08)\end{array}$ & $\begin{array}{l}-0.02 \\
(0.07)\end{array}$ & $\begin{array}{l}-0.01 \\
(0.06)\end{array}$ \\
\hline Word Recognition & $\begin{array}{l}0.21^{\star *} \\
(0.08)\end{array}$ & $\begin{array}{l}0.19^{\star \star \star} \\
(0.07)\end{array}$ & $\begin{array}{l}0.14^{\star *} \\
(0.06)\end{array}$ & $\begin{array}{l}0.12^{\star \star \star} \\
(0.03)\end{array}$ \\
\hline Oral Reading & $\begin{array}{c}0.02 \\
(0.05)\end{array}$ & $\begin{array}{c}0.02 \\
(0.03)\end{array}$ & $\begin{array}{c}0.07 \\
(0.06)\end{array}$ & $\begin{array}{l}0.07^{*} \\
(0.04)\end{array}$ \\
\hline Oral Reading Questions & $\begin{array}{c}0.15 \\
(0.10)\end{array}$ & $\begin{array}{c}0.15^{\star} \\
(0.08)\end{array}$ & $\begin{array}{c}0.07 \\
(0.07)\end{array}$ & $\begin{array}{c}0.06 \\
(0.05)\end{array}$ \\
\hline Average Score & $\begin{array}{c}0.13^{\star} \\
(0.07)\end{array}$ & $\begin{array}{l}0.13^{\star \star \star} \\
(0.05)\end{array}$ & $\begin{array}{r}0.08 \\
(0.07)\end{array}$ & $\begin{array}{l}0.06^{\star *} \\
(0.03)\end{array}$ \\
\hline Joint Test of All Differenc & & & & \\
\hline $\mathrm{Chi}^{2}(6)$ & 13.89 & 16.16 & 13.00 & 17.80 \\
\hline$p$-value & 0.031 & 0.013 & 0.041 & 0.007 \\
\hline
\end{tabular}

Note: This table displays the estimated effects of the treatment on students' standardized reading test scores. The first two columns report results from the first follow -up survey and the last two columns report results from the second follow-up survey. Columns 1 and 3 report an estimate of the average difference betw een the control and treatment students' test scores, without controls, from the first and second follow -up surveys, respectively. Columns 2 and 4 report an estimate of the average difference betw een the control and treatment students' test scores from the first and second follow -up surveys, respectively, controlling for district fixed effects and demographic characteristics, namely age, gender, body mass index (BMI) (and their interactions), number of siblings, religion, language, and baseline reading score. Standard errors are clustered by school and show $\mathrm{n}$ in parentheses. * indicates statistical significance at the $10 \%$ level, ** at the $5 \%$ percent level, and ${ }^{\star \star \star}$ at the $1 \%$ level. The last rows of the table report the Chi ${ }^{2}$ statistic and p-value from a test of the joint significance of all the coefficients on the treatment indicator from the regressions for the individual components of the reading tests estimated in a system of seemingly unrelated regression equations. 
Table A1: Attrition Patterns - Follow-Up Two

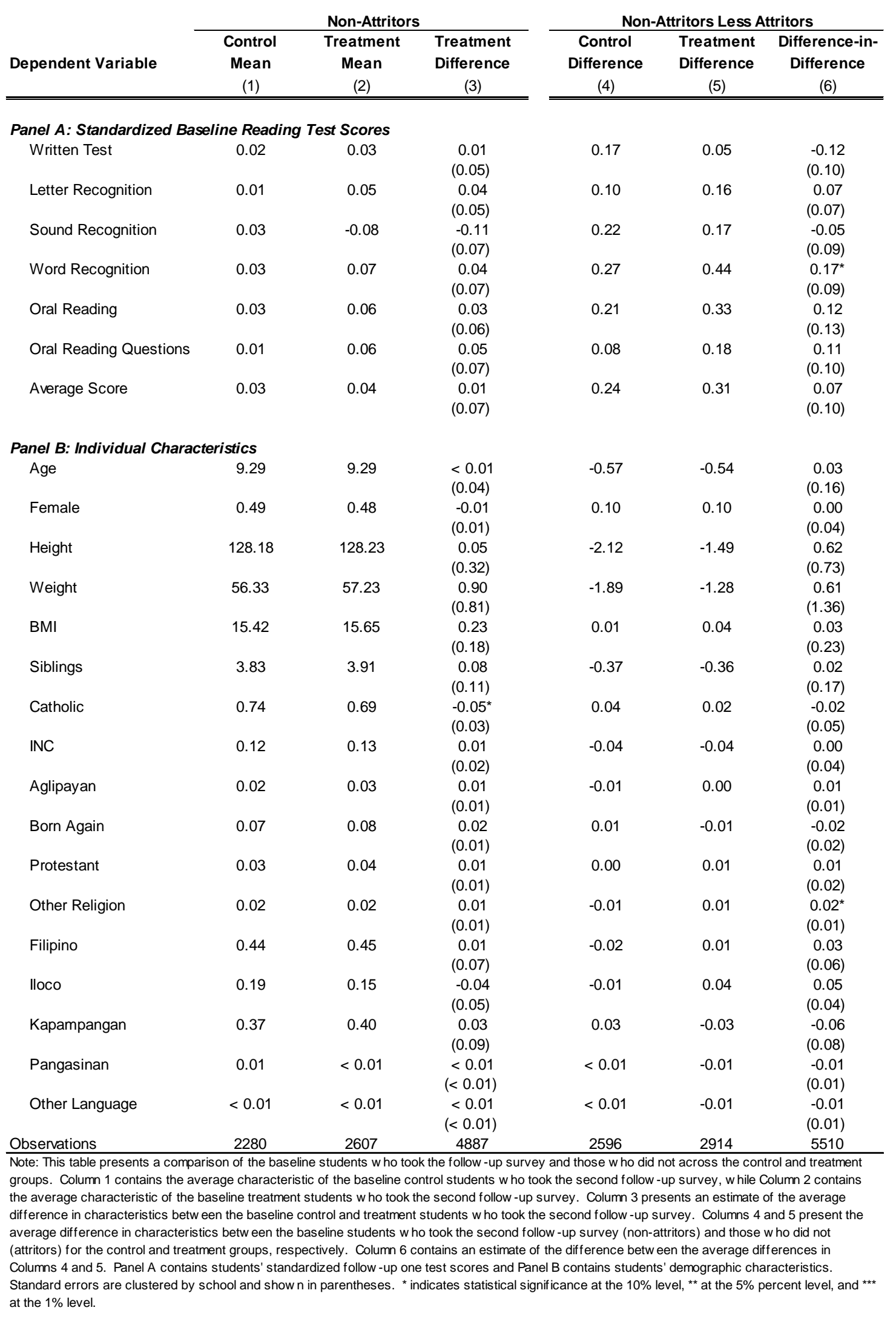

